\title{
A passion for environmental sociology. Exploring links between social environmental sciences, interdisciplinary integration and sustainability with Professor Riley E. Dunlap ${ }^{1}$
}

\section{Joan David Tàbara Daniel Polo}

Universitat Autònoma de Barcelona. Institut de Ciència i Tecnologia Ambientals 08193 Bellaterra (Barcelona). Spain

\begin{abstract}
Professor Riley E. has been one of the "founding fathers» and still is one of the most outstanding academics of contemporary environmental sociology. In fact, it is not possible to understand the development of this discipline, which now extends over three decades, without understanding his contribution. In this research note, we use an approach which combines biographical, historical and personal aspects to underline some of the most important hallmarks of his professional career and we transcribe the content of an interview carried out in May 2004 at IEST-UAB, Barcelona. We use this dialogical narrative tool to further understand broader critical issues such as the role of social science in sustainability science and the possible evolution of environmental sociology towards an ecological sociology. The difficulties encountered by environmental sociology in its process of institutionalisation are to a large extent also representative of the power inequalities, dysfunctions and resistances of the existing systems of the production of environmental and sustainability knowledge with "scientific authority» that limit the emergence of innovative interdisciplinary and integrative approaches which include the insights from social sciences.
\end{abstract}

Key words: Riley E. Dunlap, environmental sociology, sustainability, biographical approach.

Resumen. Pasión por la sociologia ambiental. Una exploración de las interrelaciones entre ciencias socioambientales, integración interdisciplinaria y sostenibilidad con el profesor Riley E. Dunlap

El profesor Riley E. Dunlap ha sido uno de los «padres fundadores» y sigue siendo uno de los académicos más destacados de la sociología ambiental contemporánea. En realidad, no es posible entender el desarrollo de esta disciplina, la cual cuenta ya con más de tres décadas de desarrollo, sin su contribución. En la presente nota de investigación, se trabaja desde una perspectiva que combina los aspectos biográficos, históricos y personales, con algunos de los momentos y las aportaciones más importantes de su carrera profesional, y se expone el contenido de una entrevista realizada en mayo del 2004 en el ICTA-UAB, Barcelona.

1. This research has benefited from the EU-DGXII WP1 Matisse Project (on new Tools and Methods for Integrated Sustainability Assessment) and also from the publications services of Autonomous University of Barcelona. 
Utilizamos esta herramienta narrativa y dialógica para profundizar en aspectos cruciales y más amplios, como el rol de las ciencias sociales en la ciencia de la sostenibilidad (sustainability science) y la posible evolución de la sociología ambiental hacia la sociología ecológica. Las dificultades encontradas por la sociología ambiental en su proceso de institucionalización internacional son, en gran parte, también representativas de las desigualdades de poder, de las disfuncionalidades y de las resistencias de los sistemas existentes de producción de conocimiento ambiental y de la sostenibilidad "con autoridad científica", las cuales limitan la emergencia de perspectivas interdisciplinares e integradas que incluyan a las ciencias sociales.

Palabras clave: Riley E. Dunlap, sociología ambiental, sostenibilidad, método biográfico.

\section{Contents}

1. Brief profile and introduction, by J. David Tàbara

2. A dialogue with Professor Riley Dunlap
3. Concluding remarks: exploring links between social environmental sciences, interdisciplinary integration and sustainability

References

\section{Brief profile and introduction, by J. David Tàbara}

I first met Professor Riley E. Dunlap back in the spring of 1989 in the small city of Udine, in the beautiful region of the Friuli, North-Eastern Italy. This was at the time of the unforgettable meeting organised by professor Raimondo Strassoldo, from Palermo University, entitled «Environmental Constraints in the Social Organization of Space» and sponsored by the Research Committee on Social Ecology of the International Sociological Association (RC 24). For many people, and particularly for young researchers-to-be like me, that conference deeply influenced the future of our professional careers. At that moment, apart from the brave contributions of authors such as Riley Dunlap, William Catton, Frederick Buttel and Alan Schnaiberg, very few social scientists dared to talk of or even had ever heard about the emerging field of «environmental sociology». Indeed, this was the beginning of a series of important international meetings that would help to consolidate the field. First, there was the one celebrated at the World Congress of Sociology in Madrid in 1990 where an informal Research Group on Environment and Society was created. Then, two years later, the first international meeting using the word «Environmental Sociology» was held in the Netherlands, and saw the merger of ISA's RC 24 on social ecology with the new research group on environment and society to form the current RC 24, known as the Research Committee on Environment and Society ${ }^{2}$. And third, in Valencia, Ernest Garcia organised another meet-

2. The meeting was called Current Developments in Environmental Sociology and was celebrated in Utrecht, Holland. 
ing in March 1992, where Alan Schnaiberg, James O'Connor as well as Riley Dunlap were among the invited speakers ${ }^{3}$. I personally remember those heated discussions first in Udine to phase out the group on social ecology, then in Madrid, when the founding members of what became the new RC 24 avoided the expected denomination of «environmental sociology» and opted for the more open, less disciplinary nomenclature of the one currently existing «Environment and Society». And also in Valencia, where the epistemological and theoretical conflicts between the different approaches to environmental sociology of the famous professors were more than visible. To my pleasure, given my great need to learn a discipline which could not be learnt or studied anywhere in Spain, Professor Dunlap had been present in all of these meetings and I must say that seeing his energy and his conviction in building the discipline has been very inspiring for me during all these years.

Indeed, by that time, Professor Riley E. Dunlap had already been actively involved in establishing the discipline for nearly two decades. Dunlap was the first social scientist to study empirically the beliefs, values and the social demographics of what he referred to as the "Dominant Social Paradigm», and relate them to concern for environmental quality and environmental activism (Dunlap and Gale, 1972; Dunlap, 1975; Dunlap and Van Liere, 1984). Together with William Catton, he was one of the first to use regularly the expression «environmental sociology» in top social science journals, trying to show the commonalities between the objects of study, research questions and practitioners in the field (Dunlap \& Catton, 1983; Dunlap \& Catton, 1979a). His efforts with Catton to clarify mainstream sociology's implicit «human exemptionalism paradigm» and their call for a «new ecological paradigm» attracted a great deal of attention and debate (Catton and Dunlap, 1978, 1980). Also with Kent Van Liere, he developed a measure aimed a elucidating the core elements of the «New Environmental Paradigm» or «Worldview», as opposed to the "Dominant Social Paradigm». The new instrument, which was called the "New Environmental Paradigm Scale», has become the most widely used measure of ecological concern, and has been employed in a large number of studies around the world (Dunlap and Van Liere, 1978; revised in Dunlap et al., 2000; Van Liere \& Dunlap, 1980; see also Olsen, Lodwick and Dunlap, 1992; and Tàbara, 2001). Other challenging topics of study dealt with by Dunlap include the possible development of an «ecological sociology» (Dunlap \& Catton, 1992), public reaction to nuclear waste (Dunlap, Kraft and Rosa, 1993), and more recently the impact of anti-environmentalism, such as to the role of the Conservative Movement as a «counter-movement» opposing environmentalism in the climate policy field (McCright and Dunlap, 2000; McCright and Dunlap, 2003). His own views on the development of environmental sociology for its first quarter of the century can be read in Dunlap $(2002)^{4}$.

3. This meeting was organised under the auspices of the Universidad International Menendez Pelayo.

4. For an article in Spanish see Dunlap (2001). 
Since the mid seventies, Dunlap participated very actively in the consolidation and institutionalisation of environmental sociology. First in America, through the Society for the Study of Social Problems where he served as the founding chair of the environmental problems division (1973-76), and then the American Sociological Association, where he served as a member of the council (1976-1978) and also as chair (1979-1983) of the section on environmental sociology. Internationally, since the creation of RC-24, besides being a founding member, Dunlap has been part of its Executive Board and also served as its president (1994-98) and has participated in an endless list of meetings and international congresses of the field around the world. This intense activity has also been combined with the publication of some major and indispensable works on the discipline, which include Dunlap \& Michelson (2002) Handbook of Environmental Sociology and Dunlap et al. (2002) Sociological Theory and the Environment. Classical Foundations. Contemporary Insights.

As a small and recent example of his international activities, Dunlap spent a week lecturing and assisting students of the international $\mathrm{PhD}$ programme on Environmental Sciences of the Institute of Environmental Science and Technology of the Autonomous University of Barcelona in May 2004 from which we transcribe below a recorded interview held during his stay ${ }^{5}$. In the present paper we use his vast knowledge and experience to further explore broader critical issues such as the role of social science in sustainability science and the possible evolution of environmental sociology towards an ecological sociology. Indeed, the difficulties encountered by environmental sociology in its process of institutionalisation are to a large extent also representative of the power inequalities, dysfunctions and resistances of the existing systems of the production of knowledge with "scientific authority», which limit the emergence of innovative interdisciplinary and integrative approaches which include the insights from social sciences.

Dunlap received his PhD from the University of Oregon in 1973 with the support of a fellowship from Resources for the Future, Inc. Most of his career (1972-2002) was linked to the development of the pioneering environmental sociology program at Washington State University (WSU). Dunlap was appointed Gallup Fellow in Environment at the George H. Gallup International Institute, where he served as Project Director for a 24-nation environmental opinion survey in 1992 (Dunlap, Gallup \& Gallup, 1993; Dunlap \& Mertig, 1995). More recently he was appointed Gallup Scholar for Environment with the Gallup Organization, where he serves as advisor for Gallup's environmental surveys in the U.S. From 1997 to 2002 Dunlap was Boeing Distinguished Professor of Environmental Sociology at WSU, and then he became Donner Professor at Åbo Akademi University in Turku, Finland. In 2005 he moved back to the United States to the University of Central Florida and in 2006 he

5. The interview has been transcribed by J. David Tàbara and Daniel Polo, and verified by Riley E. Dunlap in May 2006. Section 4 and the additional references which were mentioned during the interview have been added by J. David Tàbara. 
became professor of sociology at Oklahoma State University where he joins a large environmental sociology group.

In sum, Dunlap is of the most active academics participating worldwide in the development of environmental sociology. With his numerous awards and nearly 200 publications, including books and articles published in leading international journals, there is an immense amount of knowledge that we can and we should learn from him.

J. David Tàbara Spring 2006

\section{A dialogue with Professor Riley Dunlap}

Interview held at

ICTA, UAB, 28 May 2004

As a first question I would like to know what are your personal impressions on the evolution of environmental sociology. In particular, what have been the most outstanding milestones in the evolution of this discipline?

Well, when I think of key milestones I think of organisational developments, so a really critical milestone was the founding of the Section on Environmental Sociology in the American Sociological Association, which was formalized in 1976. That was very significant. The Rural Sociological Society had a Natural Resources Research Group with a longer history, and in 1973 I founded the Environmental Problems Division of the Society for the Study of Social Problems. But both of those organisations were pretty small, so to have ASA recognize environmental sociology was a big thing. And then, to my surprise, something which had began to occur when we first met, in Udine in 1989, was that environmental sociology began to spread around the world. So a second and a very significant milestone was the formation in the early nineties of the Research Committee on Environment and Society (RC 24) within the International Sociological Association. This was a very interesting development mainly because we took over the existing Research Committee on Social Ecology, in sort of a bloodless coup, and that was a quite an amazing accomplishment. Normally you first set up a Working Group and then it gradually becomes a Thematic Group in the ISA, and then it typically takes years to become a Research Committee. But by taking over the Research Committee on Social Ecology we managed to get our Research Committee in just two years. That was very significant because Research Committees are automatically given 16 sessions at ISA World Congresses, whereas Working Groups are given only 2, so the new RC 24 has a full slate of sessions already by the 1994 Congress in Bielefeld. So both in America and then 18 years later within the International Sociological Association, we increasingly managed to gain institutional recognition for environmental sociology. To have major sociological 
organizations recognize environmental sociology in this way was a major source of legitimacy for our field.

The other milestones are more awkward to talk about because they are intimately involved with my own personal history. I really liked the term «environmental sociology" because I got interested in environmental issues quite early, when I was in graduate school, by studying student ecology activists who participated in the 1970 Earth Day. Then I became an assistant professor at Washington State University in 1972 and was encouraged to some degree to continue to do research on environmental issues. But no one was using the word environmental sociology in those days, and when I came out of grad school I used «man-environment relations» to describe my interests on my vita. This was the term that environmental psychologists and some other social scientists were using, but with feminism rapidly emerging I didn't feel comfortable using it. I really liked the word environmental sociology, but of course to define yourself in terms of something that you don't even know exists is very awkward. So a milestone for me was to figure out what environmental sociology was going to be. Within two years, by 1975 when we proposed the ASA Section, people were beginning to use the word environmental sociology. If there was going to be something called environmental sociology, I wanted to know what it would be. And this provided the impetus or stimulus for a presentation at the 1976 ASA meeting with Catton that contained the seeds of our first article, "Environmental Sociology: A New Paradigm» ${ }^{6}$ as well as several others. For me, publishing an article which offered a definition of our new field is a personal milestone, and then to my good fortune the article ended up getting a good deal of attention.

I was definitely influenced by a number of things, such the 1975 article by Allan Schnaiberg on the societal-environment dialectic ${ }^{7}$ and a book chapter by William Burch ${ }^{8}$, who was one of the very first to study the correlation between race, class, and exposure to pollution. I thought that if there was going to be an environmental sociology, it should study environmental variables. It was that simplistic. Why did we have something called political sociology? Because that field studies political phenomena, or to use a traditional term, political variables. This simple realization was important to me, because at the time people studying environmental issues focused on environmental activism or public attitudes or the construction of environmental problems. So this was my stimulus to take the environment seriously. If we are going to have a legitimate field, one that is unique, it will be so on the basis of the nature of the

6. William R. Catton, Jr. and Riley E. Dunlap (1978). «Environmental Sociology: A New Paradigm». The American Sociologist, 13: 41-49.

7. Allan SCHNAiberg (1975). «Social Syntheses of the Societal-Environmental Dialectic: The Role of Distributional Impacts». Social Science Quarterly, 56: 5-20.

8. William R. BurCH (1976). «The Peregrine Falcon and the Urban Poor: Some Sociological Interrelations». In P. J. RichERSON and J. McEvoY (eds.), Human Ecology: An Environmental Approach. North Scituate, MA: Duxbury. 
variables and phenomena that we look at. That led to the early distinction between the sociology of environmental issues and a true environmental sociology, a field defined as the study of environmental variables or societal-environmental relations.

So the legitimacy of being able to use the term environmental sociology, which was achieved mainly due to the formation of the ASA Section, but was helped a bit by my first article with Catton (Catton and Dunlap, 1978), involved two of my personal milestones. But if I may expand on this, the series of articles I wrote with Catton had a very pragmatic beginning, to legitimate and define the field of environmental sociology by emphasizing its focus on environmental variables. Our interest in environmental variables is what led to our paradigm argument. Sociologists are not really supposed to look at environmental variables. We are supposed to examine social and cultural phenomena, otherwise you can be accused of being geographical or environmental determinists. So our recognition that a real environmental sociology would require a focus on environmental variables is what led to our explication and critique of the discipline's "human exemptionalism paradigm" and our call for replacing it with an «ecological paradigm» (Catton and Dunlap, 1978, 1980). Thus, the series of articles with Catton had a very pragmatic beginning. I wanted to be able to use the term "environmental sociology», but I didn't know what in the heck it meant, so I began writing stuff with Catton to help define the field.

\section{You have already mentioned some, but what were the main difficulties you found in the beginning in setting up the field of environmental sociology? And the rewards?}

I think that the key difficulty perhaps in my case was the sense shared by many colleagues that environmental issues were just a fad. Although I was encouraged to a degree by some people to keep up with my environmental research, one of my first Department Chairs at Washington State warned me about the danger of tying my career to the so-called «band-wagon». He said suppose all the concern about the environment is just a fad, then what will do you do when it dies out? He was basically warning me of the danger of defining myself professionally with a topic that was stimulated by a social movement, as social movements come and go. In fact, many social movements in the sixties and seventies did die out soon, but I was confident that environmentalism was going to last. Yet, studying environmental activism and public opinion, or what I called the «sociology of environmental issues», made me quite aware of the need for a real environmental sociology. I wanted to see a field that would seriously study environmental conditions, like the impact of oil shortages and air pollution on differing social classes, so that even if societal attention to environmental issues faded away we still could have something to deal with. So, the first difficulty I encountered was overcoming colleagues' scepticism that environment was more than just a passing fad, and that it was okay to define oneself as an «environmental sociologist» and commit yourself to this new field. 
But helping create this new field led to a second difficulty. When I began to consider what would be needed to have a field of environmental sociology, one that took environmental conditions seriously, I looked at other fields, especially geography. I noticed that geographers had received a lot of justifiable criticism for various forms of "environmental determinism", especially "climate determinism». Sociologists understandably reacted negatively to efforts to attribute democracy to societies living in certain climates. Yet, Catton and I felt that in rejecting environmental and biological determinism, sociologists had gone to the opposite extreme of endorsing sociocultural determinism. Especially in America in the seventies, where the "Dominant Social Paradigm» took abundance, growth, progress, etc. for granted, sociologists were influenced by this cultural mood (Catton and Dunlap, 1980). The idea that there could be limits to growth, that the environment could somehow play a key role in affecting the future, was something that was truly foreign to the discipline.

In this context I must say that the 1973-74 energy crisis had a profound effect on me, and was another personal milestone. I had grown up in the postWorld War II generation, and as teenagers we cruised around town in our cars and could find a gas station open all night long and get gas for 25 cents a gallon. Getting gas was not much different than going to the refrigerator and getting food. You just took it for granted. But in December of 1973 I was coming back to Washington State after Christmas vacation in California when I got stuck in a gas station line over four hours late at night and I was really worried that I was running out of gas. That was really a significant experience. I thought: «My God! Modern industrial societies are exempt from material constraints [...] I don't think so! I can't get home, it's dark, it's raining, it's cold and my family and I may be stuck here». So the energy crisis was a key experience for me, and it along with some later writings such as Schnaiberg's 1975 article analyzing the energy crisis, made me think that we need to do more than study Sierra Club members and environmentalism, we need an environmental sociology which is concerned with studying the relationships between modern industrial society and the biophysical environment. And of course, this made it obvious that sociology needed to break out of its traditional way of thinking.

The reaction in mainstream sociology to the energy crisis and talk about «limits to growth» that accompanied it was a vivid illustration of what Catton and I later called the Human Exemptionalist Paradigm, or the idea that modern industrial societies are literally exempt from environmental constraints by our advanced technology and science. Leading sociologists like Daniel Bell, Robert Nisbet, and Seymour Martin Lipset all responded sceptically to the talk about limits. Most notably, Daniel Bell said that if there are limits to growth, then surely they are social and not physical ${ }^{9}$. While Bell made some

9. See Daniel BeLL (1977). «Are There Social Limits: to Growth?», in K. D. WiLsON, Prospects for Growth. Changing Expectations. New York: Praeger. 
good points, like emphasizing limits of distribution, he and the other mainstream sociologists simply rejected the possibility of environmental limits and in the process illustrated the dominance of human exemptionalist thinking within our discipline in the seventies.

At the same time, the emphasis on limits to growth was a weakness of early environmental sociology. Catton was certainly a strong believer that we were running out of oil ${ }^{10}$, and I found myself, like many others, buying into the "limits to growth" notion because the thesis of the Meadows, et al book ${ }^{11}$ seemed clearly validated by the first energy crisis. So, in a sense, early environmental sociology in the U.S. became too preoccupied with resource scarcity because we were heavily influenced by the debates over "limits» and the experience of the energy crisis. To relate this to Catton's and my analysis of the three functions of the environment ${ }^{12}$ - the environment as a supply of resources or "resource depot», the environment as «living space», and the environment as "waste repository»- environmental sociology in America in the seventies was too preoccupied with resource scarcity, focusing on the energy crisis and the limits to growth. Only later did we begin to pay more attention to pollution problems, such as those at Love Canal.

Let me turn to your question about «rewards». The fact that many environmental sociologists were fairly young and willing to gamble a bit, especially after the energy crisis, and commit our careers to what some saw as a fad, helped us believe that we were doing something important that sociology at large hadn't been doing before. This created the sense of being a «small oppressed minority", but also helped us create what Fred Buttel later called an espirit de $\operatorname{corp}^{13}$, and downplay our differences. Whether Marxian or Durkheimian in orientation, we were all looking at the biophysical environment and the larger discipline was ignoring it. Some close relationships emerged from this, like the one between Fred and myself, as we believed that environmental problems were here to stay and we felt that they deserved sociological attention. So that was a reward.

\section{Now we would like to talk about sustainability, and the role of environ- mental sociology in it. For instance, the other day you mentioned some of the}

10. See William R. CatTon, Jr. (1980). Overshoot: The Ecological Basis of Revolutionary Change. Urbana, IL: University of Illinois Press.

11. D. Meadows, D. L. Meadows, J. Randers, \& W. W. Behrens III (1972). The Limits to Growth. New York: Universe.

12. William R. Catton, Jr. and Riley E. Dunlap (1989). "Competing functions of the Environment: Living Space, Supply Depot, and Waste Repository», paper presented at the Conference on Environmental Constraints and Opportunities in the Social Organisation of Space sponsored by the ISA, RC on Social Ecology, Udine, Italy, June. For a more recent version, see Dunlap and Catton (2002).

13. Frederick H. BuTTEL, «New Directions in Environmental Sociology». Annual Review of Sociology, 13 (1987): 465-488. 


\section{various books on sustainability published in the 70 s which then disappeared. What happened to them? What were they about?}

You know, the Limits to Growth was published on 1972, and the energy crisis came in 1973-74. Already by 1976-77 people were talking about how we were running out of energy and were not living within ecological limits, that we were living unsustainably, and so forth. But nowadays when we speak of sustainable development many people seem unaware of the fact that there was a minor flood of literature in the late seventies and early eighties on the "sustainable society». I used as a textbook in one of my early courses on environmental sociology a book by Dennis Pirages ${ }^{14}$, he is a political scientist, called The Sustainable Society. But you also had Hazel Henderson's book, popularizing sustainable economics ${ }^{15}$. Another British analyst, James Robertson, also had a book on that topic ${ }^{16}$. And then you had a book by Warren Johnson, Muddling Towards Frugality ${ }^{17}$. In Canada, interestingly, in many ways more progressive than the USA, there was a series of four volumes sponsored by a research council on the so-called "conserver society" which was then squeezed down to one volume ${ }^{18}$. But among all those it is the Pirages' volume which sticks in my mind. That was the key book for convincing me that we needed to have a sustainable society [a point emphasized in Dunlap and Catton, 1983] and it foreshadowed later concerns with sustainable development ${ }^{19}$.

But then an amazing thing happened. Ronald Reagan got elected President and the whole ethos in America changed. Jimmy Carter had said that «we're running out of oil and we need to learn to do with less", but Reagan came in and said «there are no limits, just follow me and free the market, get rid of government regulations and we'll be great again!». It was literally as if someone went to the library and threw away the above books that had just come out, and they just disappeared.' And this shows the influence of context, of being fortunate to publish at the right time. For instance, right after the Meadows book came out we had the energy crisis, and it gave instant validation for their thesis. But Duane Elgin came out with a book on «voluntary simplicity» just as Reagan came into office, and it simply died-although a new edition came out

14. Dennis C. PIrages (ed.) (1977). The Sustainable Society. New York: Praeger.

15. Hazel Henderson (1978). Creating Alternative Future. New York: Penguin.

16. James RoberTSOn (1978). The Sane Alternative. Minneapolis, London: Villiers.

17. Warren JoHnson (1978). Muddling Towards Frugality. Boulder, CO: Shambala.

18. In 1973, The Science Council of Canada published the report The Conserver Society, stating that «Canadians, as individuals, and their governments, institutions and industries, (must) begin the transition from a consumer society preoccupied with resource exploitation to a conserver society engaged in more constructive endeavours». The four-volume report was summarized in K. Valaskakis, P. S. Sidell, J. G. SMith and I. FitzPatrickMARTIN, The Conserver Society. New York: Harper-Collins.

19. In particular, the famous book by the World Commission on Environment and Development (1987). Our Common Future. Oxford: Oxford University Press and the subsequent UN «Earth Summit» in Rio de Janeiro. 
many years later ${ }^{20}$. The Reagan years stimulated the «decade of greed» in America. You know, «the market is God, greed is good, make as much money as possible and enjoy it», ideas popularized in the movie with Michael Douglas as the infamous banker ${ }^{21}$.

\section{And particularly now, what is the current role of environmental sociology for the reflection on sustainability? And if possible on sustainability science, it is there any role at all?}

Well, it sounds like folks like you are providing one $e^{22}$. I would say, in general, in Europe perhaps there's been more along these lines, because everything from Agenda 21 to the whole notion of the need for sustainability has gained much more of footage in Europe. It seems to me that I see my European colleagues contributing to sustainability work more than in the US, because of course now the situation is very dire. We never dreamed it could be possible, but now Reagan is looking good in comparison [to the G. W. Bush Administration]. I mean, America is so totally unfocused on sustainability at present. So I have to be honest and say that my sense is that for US environmental sociologists sustainability is not a big issue, sadly, like it is over here.

I have to go back to one of my publications on What Environmental Sociologists Have in Common ${ }^{23}$ where basically I believe we ended by saying that clearly we need to move towards a more sustainable society and the work of environmental sociology ought to be trying to figure out what a sustainable society would look like and then how we might get there. So from the very beginning, even in those old days, I think sociology had a key role to play. People were talking about a sustainable society and now we talk about sustainable development and sustainability. So when I think of the challenges they are still here, and I think environmental sociology, and sociology in general, has a tremendous amount to offer. In trying to figure out what a sustainable society or sustainability would look like, clearly social scientists are going to have a key role because we are talking about changing society, changing behavior, but also how to get there. We need sociological perspectives and tools on institutional change, the role of NGOs, the role of social movements, and so forth. Sociologists more than anyone, with the possible exception of political scientists, focus on these phenomena. We know that NGOs for example have a key role, the environmental movement must play a key role, institutions have to change, etc.,

20. Duane Elgin (1981). Voluntary Simplicity. New York: Willam Morrow. Revised edition published by Harper in 1998.

21. The film was Wall Street where Michael Douglas played the villainous Gordon Gekko performing a speech where he would go on saying that "greed is good» and which would resonate the emerging mood of the American society of the time.

22. See Robert W. KATES et al. (2001). «Sustainability science». Science, 292 (5517): 641. Kasemir, B.; Jäger, J.; Jaeger, C.; Gardner, M.T. (eds.). Public Participation in Sustainability Science. A Handbook. Cambridge: Cambridge University Press.

23. R.E. Dunlap \& W. CaTton (1983). 
so I can't imagine how there can be a sustainability science without a sociological and social science component. We need to talk about culture and cultural values and how they need to shift, and then we will to bring that down to the level of individual attitudes and values and behaviour. So environmental sociology and environmental social science have key roles to play.

So what about the integration of disciplines, methods, and knowledge? What is your view about the current debate on the integration of sciences, between natural and social sciences? How can this interaction take place? Can social environmental science develop independently — without integration - from natural sciences? Does environmental sociology need to maintain a certain degree of methodological distinctiveness in order to survive?

Well, these are tougher questions... I can try first to give you a superficial overview, then try to work deeper down, and perhaps then give you some references... I think sustainability science is an excellent example in terms of the issues we need to address. I don't know how we would integrate sciences very well, but if we take crucial issues like the need for sustainability then it opens the door for some integration. One of more interesting and positive developments I saw starting in the US in the mid- to late-nineties, which was kind of amusing for someone who had been working on environmental issues for so long, is that because of growing awareness of climate change, ozone depletion, deforestation, biodiversity loss and so forth the natural scientists, and particularly the climatologists, finally realised: «Oh my God!, these are people problems! It is people who are creating these problems and we are not going be able to solve them unless people change their ways». And for the first time I went to a meeting, an interdisciplinary conference, and I recall the natural scientists actually saying "Oh, you're a sociologist!? Can I talk to you?». They said things like "What's wrong with Americans?, Don't they realize that $\mathrm{CO}_{2}$ is creating the greenhouse effect and it's going to change the climate? Why aren't people changing their lifestyles?». It goes both ways, I don't think sociologists were making much of an effort to reach out to natural scientists, but it wasn't until these huge, incredibly difficult problems gained credibility among natural scientists that they realized the need for us.

So the current possibilities for working together, collaborating, are better than ever before. And that's because the natural scientists and progressive governments, who recognise the problems, realise that environmental problems are people problems, and sociologists study people. But I don't have a strong position on the integration of sciences. People like Peter Dickens in the UK are working hard to develop a real theoretical perspective, in Peter's case a kind of Marxian view, on how we should do this ${ }^{24}$. I don't know how I feel, I don't

24. See P. Dickens (1992). Society and Nature. Towards a Green Social Theory. Hemel Hempstead: Haverster; and P. DICKENS (2000). Social Darwinism: linking evolutionary thought to social theory. Buckingham, UK: Open University. 
know the possibilities. I think there are some limits to integrating knowledge. I think the best thing is to work on topics of mutual interest and learn from one another. I don't have some kind of grand Comtean vision of putting everything together into a fully integrated science.

I think integration, where it occurs, takes place in joint work on some defined projects like analysing why current lifestyles and modern industrial societies are so unsustainable and what needs to be done make them sustainable. It's that kind of work which will bring together people from different disciplines. And in that sense, the whole notion of «sustainability science», which at one level is just a jazzy advertising thing, but at another level is very meaningful, may occur.

On the last question, I think that there is some degree of distinctiveness, although I've never been a purist. A real purist sociologist might say that «we're not psychologists, we don't look at individual behaviour, we look at social structure, institutions and so forth». I don't know that we need purism to survive, but I think it brings to this debate a sense of our unique contribution. I've seen truly brilliant natural scientists having the most naive perspectives on environmental issues, saying: «We just need to educate the public. If you just give them information then it will work». Twenty five years of social research shows that just providing information never works. You have to do so much more. If we want people to recycle you don't tell them: «garbage is bad, recycling is good». You create an integrated recycling program so that the truck that comes to pick up the garbage also picks up the recycling, and then whether the people are concerned about the environment or not, they will in fact recycle. So building rewards and costs in to induce behavioural changes and making behaviour easy to perform, these are things about which natural scientists really are naïve. They are sometimes as illiterate or naïve about social phenomena as people like myself are about some of the things they study.

So what is the role or to which extent do methodologies like polls or others have in integrating knowledge, for example, from natural sciences? Is it possible at all? How could it be done?

I want be cautious here. My guess is that in general because so many natural scientists, not all, are heavily quantitative they often find it easier to deal with social scientists who also bring numbers of some type to bear on the issues. I don't know if that is absolutely essential for collaboration or even integration. I think a lot of qualitative work, to use an overly simplistic dichotomy that contrasts it with quantitative, illustrates that social scientists can do very good work. For example, analyzing the processes by which problems become constructed by the media and by activist groups, and the effect that this has on getting problems onto the political agenda, and the effect of this on policy, are valuable. Work along these lines offers excellent insights and would help natural scientists without necessarily involving numbers. So I don't see quantitative versus qualitative as a big issue for integration. Again, I think natural 
scientists have a «natural» affinity for quantitative work, but I think they also appreciate some of our qualitative insights.

We can look at, for example, the work in political science and policy analysis, and how they talk so much about the way policy formation and especially policy implementation is affected by what is going on in the world and how all this creates sort of a policy window of opportunity. And so if I were talking with climate scientists right now I would be emphasizing that there is a new movie coming out, and it's going to bring media people to your door that may not have been there before. This is a big opportunity to provide them with information because "The Day After" may sensitise the public. Now you're going to have to be careful, you don't want to undersell the seriousness of the problem, and don't want to be too dramatic, so be careful how you frame things. Say we're not expecting anything to happen this quickly, but the kind of things portrayed in this movie, the kind of change shown in this movie as a result of climate change, is a potential consequence of the path we are on'. Knowing how to frame an issue, how to frame one's message, that's very crucial and this is something that natural sciences just don't know yet. And so there is a great case to be made for the utility of qualitative work —on media, movements, rhetoric — so you don't need numbers.

In this last section I would like you to talk about the future, about the future of environmental sociology and in particular I would like to know your view on the development of ecological sociology $y^{25}$. To which extent do you think ecological sociology can be distinguished from environmental sociology and what are their interactions?

Well, hmm... I know David has a vested interest in this... I don't know. I can't give a clear-cut view. It would be a logical step to go from environmental sociology to a true ecological sociology. When we were pushing early on to have a field established I needed this big distinction between the sociology of environmental issues — simply taking any kind of sociological perspective on social movements, attitudes, media studies, etc. and applying it to the environmentand I said: "that's fine, after all, in many ways this is what I am doing». But we really do need an environmental sociology, we do need to bring environmental variables into our work. Now, I think we have made a lot of progress, especially if you look at the environmental justice studies and the environmental racism studies in America. And, by the way, those are certainly bigger issues in America than is sustainability. Those studies take the existence of toxic waste, of hazardous waste, or just garbage dumps for granted, and then they try to get measures of exposure to them and then correlate those with class, race, and so forth. So incorporating environmental variables into socio-

25. TÀBARA, D. (2003). «Teoría socioambiental y sociología ecológica». («Socioenvironmental Theory and Ecological Sociology»). Published in S. GINER, Teoría sociológica moderna. Madrid: Ariel. p. 431-458. 
logical analysis has become more commonplace. It really was absolute heresy almost in the seventies, but now that's been achieved. So that's a huge achievement to me.

I believe that the distinction between the sociology of environmental issues and environmental sociology is sort of comparable to environmental economics versus ecological economics. Sociology of environmental issues took mainstream perspectives and applied them to the environment just as environmental economists take neoclassical economics and analyze externalities, common property resources, and other things, but they don't question the basic economic model. Ecological economics says we have to break out of this totally human-centred view and realize that there is a biophysical world in which the economy operates, that capital and labour cannot substitute forever for resources, and so forth. It's more like a real environmental sociology in terms of recognizing the importance of the biophysical environment.

So to some degree simply getting to environmental sociology was a huge shift and I think somewhat parallel to ecological economics. It's just that in the more sophisticated versions of ecological economics you really get a full-blown ecological perspective - when you look at energy flows and other stuff that you guys look at here ${ }^{26}$ - that environmental sociology does not have. But some environmental sociologists are trying, and as you know in our early articles Catton and I argued that we needed a real ecological perspective. We argued that we need to be guided by an Ecological Paradigm, but then also mentioned certain types of insights from ecological theory. And then in a paper I gave in 1992 I used the term "ecological sociology» ${ }^{27}$. But then two things happened: I got involved with the Health of the Planet Survey with Gallup ${ }^{28}$, and with all of that work on public opinion I didn't have the time or energy to mine ecological theory, and clarify what it would mean [for environmental sociology]. But at the same time, sociologists were slowly shifting their attention gradually to ecological footprints and so on. So I guess what I'm saying

26. At the international Phd Programme on Environmental Sciences of the IEST-UAB, which currently host around a 100 students from a large number of nationalities.

27. In particular, Dunlap (1992: 23-25) argued that: «we believe that sociology is unlikely to make significant contributions to an understanding of global (or even local, for that matter) environmental change until we shed the exemptionalist blinders inherited from our founding fathers [...]. Reinvigorating environmental sociology, or the study of societalenvironmental relations, is not enough: we must develop a full-blown "ecological sociology" that studies the complex interdependencies between human societies and the ecosystems (from local to local) in which we live. [...]. It will be inherently interdisciplinary, and have to repudiate the separation from bioecology that has become conventional among contemporary sociologists who call themselves "human ecologists" but who embrace human exemptionalism as strongly as the rest of the discipline. [...] The challenge posed to our discipline by GEC is great, but the cost of ignoring it is even greater».

28. R. E Dunlap, G. H. Gallup, Jr., A. M. Gallup, Health of the Planet Survey (1992). A preliminary report on attitudes toward the environment and economic growth measured by surveys of citizens in 22 nations to date. Presented at the ISA meeting Current Developments in Environmental Sociology, held in Utrech, the Netherlands. 
is I am unsure whether we really need an ecological sociology or if environmental sociology is enough. I would be happy with an environmental sociology informed by ecological thinking. If you want to call it ecological sociology like you do, I would be happy to go back and we can put a couple of articles together. That would be nice.

One of our problems in America in particular was that there is this old, classic field called human ecology, from the Chicago School, and demographers and human ecologists basically study aggregate-level phenomena and not individuals. Well, environmental sociologists and sociological human ecologists had a strained relationship from the outset, as the human ecologists thought that we were steeping on their toes. Perhaps they should have been sympathetic, but they weren't because we accused them of buying into the mainstream exemptionalist thinking, and pointed out that they really didn't study the environment, they only studied the social environment [see Dunlap and Catton, 1979b]. So if you look at sociological human ecology in the seventies, they were doing things like studying migration, but they weren't using energy. When they wanted to explain why people moved to the suburbs their measure of the environment in the old POET model was the percent of nonwhites in the area. So we environmental sociologists came along and said «these guys are just [...] you know, they buy into human exemptionalism, they are totally non-environmental, they are a problem». They did have the tools, if they wanted to look at the environment, and they had perspectives that they could be useful. I always was in favour of learning from them, but the fact that we criticized them created problems.

But anyway, because human ecology and demography — and they usually go together, as when a sociology department offers human ecology it usually offers demography - programmes existed at Berkeley, Michigan, Wisconsin, Princeton, Brown, North Carolina, and other places where there was typically no environmental sociology, to have called yourself an «ecological sociologist» would have been nutty. So in principle, I like the idea of ecological sociology, and I think we should be moving that way. I think if we become more interdisciplinary in places like this [IEST] where you can learn from ecological economists and ecological scientists then you will inevitably become more ecological. But again, I would say, any environmental sociology that looks at the world ecologically, to be simplistic, I would be happy with that - because we have come a long way. I'm just so happy to see sociologists, and young sociologists, come along and study environmental issues that I don't like to suggest that "we're pure, you are on the margin because you're not doing the real thing» [if not analyzing environmental variables]. So I kind of buy the idea, suggested by Fred Buttel, that whether a person does environmental sociology or the sociology of environmental issues that's great, and they're all «environmental sociologists». You may just study the social construction of environmental issues, but if you study environmental issues you are contributing to sociological knowledge. So I'm not concerned about these distinctions anymore. But in my heart, yes, I like the idea of an ecological sociology. It would 
be a nice goal to work for. But I think it will only happen with more integration, more interdisciplinary work, working with ecologists, working with ecological economists, working with natural scientists, that's the way sociologists may become ecological.

\section{Thank you very much Riley. That was great ${ }^{29}$.}

\section{Concluding remarks: exploring power relationships, environmental social sciences, and interdisciplinary knowledge integration in the need to understand unsustainability}

Addressing the questions on how academic environmental knowledge is created, institutionalised and finally provided with scientific authority and validity is of crucial importance in order to understand the making of sustainability discourses both within and outside the academic world. The extraordinary professional life of Professor Riley Dunlap provides a unique example of the role that power relationships and struggles, as well as the organisation of existing institutions, have in enhancing or limiting the development of new science approaches more in tune with the needs which emerge from unsustainability, persistent problems, and a turbulent environment. Narrative stories, biographical and dialogical approaches are powerful tools which can also be used in integrative science approaches to reframe the issues at stake and learn new perspectives which help to articulate the new complexity in a radically different way than just applying the old scientific paradigms and models to the new realities. For that, it is clear that the restructuring of environmental knowledge, e.g. towards a new more integrated and sustainably relevant one, cannot be done without a parallel reorganisation of the science and policy structures of power and institutions currently entrenched in the making of sustainability knowledge.

Noteworthy, in our exploration, Dunlap insisted that the integration of social environmental sciences with other natural sciences is not so much dependent on the type of method or tool used by social sciences - whether this would be quantitative or qualitative- but on ensuring that there is a common ground of interest for the different sciences to work together so that it is possible for all of them to contribute in a similar conditions to the understanding of the issues at stake. This raises the fundamental aspects of power, culture and equity in science production processes, and to which extent the dominance of natural science approaches over social science in the making of environmental science is mostly an expression of inequality in the current

29. At this point, Dunlap recommended that if someone only wanted to read a couple of pieces from him, first to see his personal perspective on the evolution of environmental sociology people should look at Dunlap (2002) and then to expand on his view on theory they may look at his chapter within Dunlap et al (2002). 
structure of academic knowledge production. The making of environmental knowledge is not unrelated to the structures of power and cultural frameworks embedded in the myriad of university departments, professional organisations and the like. The difficulties encountered by Professor Riley Dunlap and other pioneers of in the institutionalisation of environmental sociology both in the USA and internationally are most representative of such struggles and power inequities which now can also be observed in the attempts to institutionalise new emerging fields such as Ecological Economics, Integrated Environmental Assessment or Sustainability Science. And in turn, the fragmentation of socialenvironmental sciences in a multitude of sometimes unrelated approaches constitute an added weakness which also can be used to the advantage of the more consolidated natural sciences to inform, in a disintegrated way, the processes of policy making.

Hence, the institutional context and the power relationships embedded in the procedures of knowledge generation may constrain the development and application of environmental sciences. This is certainly, for instance, the case of Spain, which after forty years of dictatorship, saw power conflicts shift from the open social sphere to the more closed and formalised institutional ones, with a notorious illustration in the proliferation of hundreds of new departments and dozens of new universities in just a couple of decades. These, most likely, responded more to the management of power interests and ideological struggles than to the true commitment to the advancement of knowledge. This situation, in which power conflicts usually needed to be settled first before knowledge ones, may explain why in that country new interdisciplinary approaches such as environmental (or ecological) sociology, with some very odd exceptions, have not really taken off or simply do not exist. Moreover, while on the one hand such an increase in the institutional network of the academic structures may be seen by some as an increase in the democratisation of knowledge, the fact is that, again, environmental science has been dominated once more by natural sciences, which in turn limit the validity and relevance of its outputs. As has been empirically traced in the emergence of new environmental policy relevant fields such as conservation biology or even ornithology, the formal consolidation of academic careers in environmental science is a hard and extremely arduous path which can only be walked by a few astonishing individuals able to merge knowledge, conviction and passion, together with the responsible practice of creating new and innovative institutions for interdisciplinary knowledge integration.

Finally, the present contribution underlines an aspect which is relevant for those people working at the centre of interdisciplinary environmental science ${ }^{30}$, and therefore, usually at the margins of the best established orthodox disciplines which still see interdisciplinarity as more of a problem than as an advan-

30. See P. Weaver and Jan Rotmans (2005). «Integrated Sustainability Assessment: What, Why, How?». Matisse working Paper, November. www.matisse-project.net 
tage: that of the interrelationships between cultural visions, values and epistemological positions with the use of standard particular tools and methods to make «good science». The close interlinks between the two, between worldviews and rational practices, can not be overstated. Within sociology, Dunlap mentioned that human ecology had the most sophisticated tools and methods for the creation of orthodox science, but surprisingly they were not looking at the (natural) environment at all. In other words, tools and methods were not enough, a new cultural shift and vision was necessary. And as a reaction, environmental sociology emerged as a counterbalancing and powerful critique to fill that gap and to create a new articulating paradigm. However, still, and despite the three decades of its making, and now being a fast growing international scientific community, the fact is that environmental sociology has not yet achieved the same academic status as the already established human ecology in which the environment is still more often absent than not ${ }^{31}$.

\section{References}

Catton, W.R., JR.; DunlaP, R.E. (1978). «Environmental Sociology: A New Paradigm». The American Sociologist, 13: 41-49.

- (1980). «A New Ecological Paradigm for Post-Exhuberant Sociology». American Behavioral Scientist, 24: 15-47.

DunlaP, R. E. (1975). «The Impact of Political Orientation on Environmental Attitudes and Actions». Environment and Behavior, 7: 428-454.

- (2001). «La sociología ambiental y el nuevo paradigma ecológico». Sistema, 162/163: $11-31$.

- (2002). «Environmental Sociology: A Personal Perspective on Its First Quarter Century». Organization and Environment, 15: 10-29.

Dunlap, R.E.; Buttel, F.H.; Dickens, P.; Gijswijt, A. (eds.) (2002). Sociological Theory and the Environment: Classical Foundations, Contemporary Insights. Boulder, CO: Rowman \& Littlefield.

Dunlap, R.E.; Catton, JR., W.R. (1979a). «Environmental Sociology». Annual Review of Sociology, 5: 243-273.

- (1979b). «Environmental Sociology: A Framework for Analysis», in T. O'RIORDAN and R. C. D'ARGE (eds.), Progress in Resources Management and Environmental Planning, vol. 1. Chichester, UK: John Wiley, p. 57-85.

- (1983). «What Environmental Sociologists Have in Common (Whether Concerned with "Built" or "Natural" Environments)». Sociological Inquiry (Special Issue on «Sociology of the Environment»), 53: 113-135.

- (1992). «Toward an Ecological Sociology: The Development, Current Status, and Probable Future of Environmental Sociology». The Annals of the International Institute of Sociology, 3: 263-284. Reprinted in: W. V. D'ANTONIO, M. SASAKI and

31. Measured, for instance, not only by the relative prestige of sociology journals in which sociological human ecologists and environmental sociologists typically publish, but also by the greater predominance of human ecology/demography programs in leading American universities. 
Y. YONEBAYSHI (eds.). Ecology, Society and the Quality of Life, New Brunswick, NJ: Transaction Publishers, 1994, p.11-31.

- (2002). «Which Functions of the Environment Do We Study? A Comparison of Environmental and Natural Resource Sociology». Society and Natural Resources, 15: 239-249.

DunlaP, R.E.; HeFFernan, R.B. (1975). "Outdoor Recreation and Environmental Concern: An Empirical Examination». Rural Sociology, 40: 18-30.

DunlaP, R.E.; Gale, R.P. (1972). «Politics and Ecology: A Political Profile of Student Eco-Activists». Youth and Society, 3: 379-397.

DunlaP, R.E.; GalluP, JR. G.H.; GalluP, A.M. (1993). «Of Global Concern: Results of the Health of the Planet Survey». Environment, 35 (November): 7-15, 33-39.

DunlaP, R.E.; Kraft, M.E.; Rosa, E.A. (eds.) (1993). Public Reactions to Nuclear Waste: Citizens' Views of Repository Sitting. Durham, NC: Duke University Press. Dunlap, R.E.; Mertig, A.G. (1995). "Global Concern for the Environment: Is Affluence a Prerequisite?». Journal of Social Issues, 51: 121-137.

DunlaP, R.E.; Michelson, W. (eds.) (2002). Handbook of Environmental Sociology. Westport, CT: Greenwood Press.

DunlaP, R.E.; Van Liere, K.D. (1978). «The "New Environmental Paradigm": A Proposed Measuring Instrument and Preliminary Results». Journal of Environmental Education, 9: 10-19.

- (1984). "Commitment to the Dominant Social Paradigm and Concern for Environmental Quality». Social Science Quarterly, 65: 1013-1028.

Dunlap, R.E.; VAn Liere, K.D.; MertiG, A.G.; Jones, R.E. (2000). «Measuring Endorsement of the New Ecological Paradigm: A Revised NEP Scale». Journal of Social Issues, 56: 425-442.

MCCRIGHT, A.M.; DunLAP, R.E. (2000). «Challenging Global Warming as a Social Problem: An Analysis of the Conservative Movement's Counter-Claims». Social Problems, 47: 499-522.

- (2003). «Defeating Kyoto: The Conservative Movement's Impact on U.S. Climate Change Policy». Social Problems, 50: 348-373.

Olsen, M.E.; LODWICK, Dora G.; DunLAP, R.E. (1992). Viewing the World Ecologically. Boulder, CO: Westview Press.

VAN LIERE, K.D.; DUNLAP, R.E. (1980). «The Social Bases of Environmental Concern: A Review of Hypotheses, Explanations and Empirical Evidence». Public Opinion Quarterly, 44: 181-199.

TÀBARA, D. (2001). «La medida de la percepción social del medio ambiente. Una revisión de las aportaciones realizadas por la sociología». Revista Internacional de Sociología, 28: 125-168. 